\title{
Hybridisation of human resources management practices: the case of local government in France
}

\author{
Celine Desmarais \\ University of Applied Sciences \\ and Arts, Switzerland
}

Sandra Dubouloz

Université Savoie Mont Blanc, France

Arnaud Bichon

Université Savoie Mont Blanc, France

\begin{abstract}
The dissemination of New Public Management principles is transforming human resources management practices in the public sector. The transformations that have taken place follow four logics: the logics of formalisation, contractualisation, individualisation and politicisation. The article examines the consequences of the interplay of these logics on the hybridisation of human resources management practices. To this end, two complementary methodologies were used: a quantitative methodology based on a survey of 223 local authorities within a French department; and a qualitative methodology based on interviews conducted with 25 of these authorities. The results show that these logics coexist, raising questions about the micro-negotiations that allow this coexistence.
\end{abstract}

\section{Points for practitioners}

Human resources management practices in public organisations are the composite outcome of a set of different, even contradictory, logics: the logics of individualisation, 
contractualisation, formalisation and politicisation. There is no common shift towards a single new human resources management model within French local authorities. The fact that these logics are always present in different combinations is explained mainly by the internal dynamics between the stakeholders (elected officials, human resources professionals, management, etc.).

\section{Keywords}

human resources management, hybridisation, politicisation

\section{Introduction}

The spread of the performance ideal of New Public Management (NPM) through the public sector results in the hybridisation of management practices (Emery and Giauque, 2014). This is the case with public human resources management (HRM) practices. In many countries, practices based on the administrative tradition and the politicisation of management compete with logics based on NPM doctrines (Desmarais, 2008) that promote contractualisation and individualisation, as well as an increasing formalisation of HRM practices.

As at 31 December $2015,{ }^{1}$ local government in France had a 1889 million-strong workforce, employed by approximately 48,000 employers (municipalities, French departments, regions, inter-municipal organisations and public establishments). While it may not have undergone a radical reform, it is nevertheless characterised by developments inspired by NPM. In fact, the quest to control their management has prompted local elected officials to argue in favour of the contractualisation and individualisation of careers and remuneration (Biland, 2009). At the same time, the traditionally strong involvement of elected officials in recruitment and their close presence in day-to-day management lead some authors to consider French local authorities as an island of politicisation (Chevallier, 2002). Finally, the professionalisation of human resources (HR) leads to a more formalised process, hence the competition within French local authorities between the demands for modernisation, professionalisation and the involvement of elected officials.

It is therefore necessary to identify whether certain logics predominate and to analyse how the different logics present in local HRM relate to each other. Are HR practices integrated and consistent or are they disjointed and muddled?

The purpose of this article is therefore twofold: (1) to characterise HRM practices in French local authorities; and (2) to gain an in-depth understanding of the hybridisation processes at work. To do this, it uses both a quantitative (223 territorial authorities) and qualitative (30 semi-directive interviews with 25 authorities) approach.

We begin by outlining the theory behind the logic of individualisation, contractualisation, politicisation and formalisation. We then explain the methodologies used and present our main results, which we discuss in a final section. 


\section{Current developments in local HRM: a hybridisation of practices}

In most Organisation for Economic Co-operation and Development (OECD) countries, civil service management has been hinged around the objective of protecting public officials against political arbitrariness by putting an end to patronage (Dreyfus, 2000). This protection has now come under fire. Explicit and measurable performance standards, control, competition, the use of private sector management techniques, and strict discipline in the use of resources are the founding principles of NPM (Hood, 1996). Thus, a New Human Resources Management (NHRM) has emerged that puts the focus on three logics derived from the reproduction of private sector practices: contractualisation, individualisation and formalisation (Desmarais, 2008). However, these logics interact with a logic of politicisation, traditionally present in public management practices.

\section{The logic of contractualisation}

The efforts made to develop public performance and to move closer to the private sector are reflected in the dismantling of the protections and constraints of the civil servant status (Demmke and Moilanen, 2010; Shim, 2001) in order to facilitate the recruitment and dismissal of public workers. The status of local government workers dates back to the 1983 and 1984 laws. In principle, permanent jobs are reserved for civil servants; however, since 1987, recruitment conditions have been greatly relaxed in small municipalities. This means that French local authorities are characterised by a relatively high percentage of staff without civil servant status, although this figure is decreasing. ${ }^{2}$ In 2009 , nearly $30 \%$ of local government workers did not have civil servant status (Biland, 2012). In 2014, the recruitment of contract workers was the most common form of hiring (Bounakhla, 2016). ${ }^{3}$

\section{The logic of individualisation}

Public HRM is undergoing a shift from an objectifying model, characterised by uniformly applied criteria, to an individualised model, integrating criteria negotiated through interpersonal agreements (Nizet and Pichault, 2013). Long promoted by the OECD (Desmarais et al., 2007), individualisation has been at the heart of recent reforms. Tools for recognising individual performance have spread through the French civil service, as in most European countries (Shim, 2001).

Within local authorities, competition and the civil servant status were introduced quite late in the day and gave way to contradictory logics (Biland, 2010). Today, the individualisation of remuneration and careers is a subject of ongoing debate and seems to be progressing steadily, ${ }^{4}$ particularly with the introduction of merit bonuses. 


\section{The logic of formalisation}

The formalisation of HRM refers to the fact that HRM practices are documented, standardised and institutionalised (Kim and Gao, 2010). According to Nizet and Pichault (2013), both objectifying and individualising models result in the formalisation of management practices, tapping into a global trend. Thus, the weakening of statutory constraints seems to be reflected in the emergence of a formalisation centred on individualising HR tools: the management of individual skills, selection processes, evaluation based on personalised criteria and so on. French local authorities have seen their human resources function being structured over decades (Crozet and Desmarais, 2004), with the dissemination of increasingly sophisticated management tools.

However, the main contingency factor associated with formalisation is the size of the organisation (Pichault and Nizet, 2013; De Kok and Uhlaner, 2001). Smaller organisations (out of 35,357 municipalities in metropolitan France, more than one in two $(53 \%)$ had fewer than 500 inhabitants as at 1 January $2018^{5}$ ) have no choice but to adopt more informal practices due to a lack of resources.

\section{The logic of politicisation}

The political-administrative interface is the most critical link in the democratic system (Hood, 2001). In this context, politicisation is a mainstay of public organisations (Pierre, 2004). Peters and Pierre (2004: 2) define politicisation as 'the substitution of political criteria for merit based criteria in the selection, retention, promotion, rewards and disciplining of members of the public service'. This formal politicisation emphasises political influence on the recruitment and careers of civil servants. Functional politicisation refers to the alignment of administrative action with political objectives (Cameron, 2010; Dion, 1986). The politicisation of HRM can therefore be observed through two dimensions: the consideration of political issues in HR decisions; and the intervention of political stakeholders in HR processes. As such, politicisation can be related to discretionary policy or value-based policy in Pichault and Nizet's (2013) typology. French local authorities have long been considered as fertile ground for cronyism, which can be defined as an informal power practice based on the exchange of resources between elected officials (jobs, housing, etc.) and beneficiaries (political support) (Caciagli and Jun'ichi, 2001).

NPM-related reforms attempt to solve the equation between autonomy and control by simultaneously promoting the management autonomy of public officials and the strengthening of policy power (Norman, 2001). However, the real impact of NPM-related reforms on politicisation is debatable. Some authors observe a strengthening of managers' control over the conduct of public affairs (Pollitt, 1993); others see a strengthening of the position of politicians (Pierre, 1995).

Rather, politicisation depends on the characteristics of administrative systems (Pollitt and Bouckaert, 2004). Local government in France, traditionally 
characterised by the omnipresence of elected officials in certain acts of staff management (Sadran, 1987), is not showing any signs of depoliticisation. Admittedly, the effects of NPM induce a delegitimisation of local recruitment and an increasing emphasis on the professionalism of workers (Biland, 2012). However, the questioning of statutory protections seems to be fuelling the traditional demand for free administration by local elected officials (Biland, 2012). We are also seeing an escalation in the use of the spoil system (Le Saout, 2011). ${ }^{6}$

\section{From the competition of logics to the hybridisation of practices}

The loosening of the civil servant status can lead to more individualised and contractualised management, greater formalisation, or even increasing politicisation. However, the literature suggests that we are witnessing more of a hybridisation of practices. Hybrid environments borrow from different and potentially contradictory universes, values and principles of action that influence and legitimise behaviour (Emery and Giauque, 2014). The analyses of contradictions in management have focused on decoupling strategies (displaying adherence to a logic and implementing a competing logic in backroom activities) before focusing on practices that mix the different logics. Neo-institutionalist approaches have studied how plural approaches are constructed, challenged and negotiated (Skelcher and Smith, 2015), how they oppose or combine to promote new practices and new modes of organisation (Battilana and Dorado, 2010). Bishop and Waring (2016), for example, analyse the negotiations that make it possible to combine these logics at the micro level, reconcile underlying institutional tensions and contribute to the existence of a new hybrid organisational order.

\section{Methodology}

To characterise local HRM practices and analyse the underlying logics, we conducted a double study - quantitative and qualitative - within a number of French local authorities belonging to the same geographical department.

\section{Quantitative methodology}

Field of investigation. In 2014, we conducted a quantitative study with a representative sample of 223 local authorities located in the French department of HauteSavoie, ${ }^{7}$ which has 493 authorities and establishments. The survey was carried out in conjunction with the Management Centre (CDG), an organisation responsible for centralising the administrative management of a majority of local authorities (career management, occupational medicine, etc.) and providing them with advice and support (mainly legal) in their HRM and administrative management operations. ${ }^{8}$ The questionnaire was sent by email, with a telephone reminder. The objective of this approach was to characterise the HR practices of local 
authorities in terms of HRM and to observe the degrees of contractualisation, individualisation, formalisation and politicisation of HRM.

Presentation of the sample. The sample is representative of the 493 local authorities and public establishments in Haute-Savoie in terms of size, type (municipalities, public establishments, inter-municipalities and departmental council) and status (local authorities and public establishments); the vast majority of local authorities and establishments in this department are enrolled with the CDG on a compulsory or voluntary basis. Table 1 presents the distribution in terms of the size and type of authority.

The interviewees were directly responsible for HRM in their authority. Most were administrative staff: town hall secretaries $(21.7 \%)$, general managers $(11.5 \%)$ and HR staff $(25.2 \%)$. Elected officials (from very small authorities) represent only $6 \%$ of the sample.

Data processing. In order to characterise HRM practices, identify authority profiles based on these practices and analyse the interplay of the different HR logics, we conducted a principal component analysis (PCA) in conjunction with a nonhierarchical classification that leads to a typology of local authorities based on illustrative variables. The classification methods aim to divide a sample of $n$ individuals into $k$ groups or classes that are as homogeneous as possible (Thiétart, 2014). To determine the final number of classes, we used the following three usual criteria: (1) the statistical validity of the classification measured by intra- and intergroup variances; (2) the number of authorities per class; and (3) the significance of the identified groups. These criteria prompted us to opt for the five-group version. Then, we compared the averages to characterise the five classes.

\section{Qualitative methodology}

Data-collection method. The qualitative approach was based on 30 semi-directive interviews: 25 with the managers or persons in charge of human resources of

Table I. Characterisation of the sample in terms of size and type.

\begin{tabular}{lcc}
\hline Number of workers & $\begin{array}{l}\text { Number of } \\
\text { authorities }\end{array}$ & $\begin{array}{l}\text { Percentage of } \\
\text { the sample }\end{array}$ \\
\hline 0 to 5 & 88 & $39.5 \%$ \\
6 to 20 & 76 & $34.1 \%$ \\
21 and over & 59 & $26.5 \%$ \\
Total & 223 & $100 \%$ \\
Type & & \\
Municipalities & 151 & $67.75 \%$ \\
Public establishments & 71 & $31.8 \%$ \\
Departmental council & 1 & $0.45 \%$ \\
Total & 223 & $100 \%$ \\
\hline
\end{tabular}


25 local authorities in the French department between 4 November 2013 and 17 February 2014 and five with the deputy manager and manager of the recruitment/ employment/mobility unit of the CDG (see Table 2). To select the authorities, we used the theoretical sampling criteria identified by Hlady Rispal (2002): theoretical representativeness; variety; a balanced distribution between cases; and the potential wealth of the available data. We guaranteed the anonymity of the data collected and returned the results to the stakeholders.

The semi-directive interviews, which lasted an average of 90 minutes, focused on the characteristics of HRM approaches and the role of the different stakeholders in these approaches. More specifically, we analysed the recruitment processes, focusing on one of the latest organised recruitments.

\section{Data analysis}

We conducted two types of analysis. On the one hand, a typological lexical analysis without bias was carried out to confirm the four logics identified during the PCA and in line with the literature. On the other hand, a content analysis allowed a more in-depth understanding of the processes of the hybridisation of practices.

Table 2. Semi-directive interviews: authorities and functions of the interviewees.

\begin{tabular}{|c|c|c|}
\hline Authority & Function of the interviewees & $\begin{array}{l}\text { Number of } \\
\text { authority } \\
\text { workers }\end{array}$ \\
\hline Departmental council & HRD & Over 200 \\
\hline 2 urban communities & $\begin{array}{l}2 \mathrm{HRD} \\
2 \mathrm{HR} \text { managers }\end{array}$ & Over 200 \\
\hline 8 large municipalities & $\begin{array}{l}8 \mathrm{HRD} \\
\text { I recruitment manager }\end{array}$ & Over 200 \\
\hline 3 medium-sized municipalities & $\begin{array}{l}3 \text { general directors of services } \\
\text { I HR manager }\end{array}$ & 50 to 200 \\
\hline I public-private enterprise & I HRD & 50 to 200 \\
\hline $\begin{array}{l}6 \text { large groupings of } \\
\text { municipalities }\end{array}$ & $\begin{array}{l}2 \text { general directors of services (DGS) } \\
\text { I assistant general director (DGA) } \\
4 \text { HRD } \\
\text { I HR assistant }\end{array}$ & 50 to 200 \\
\hline $\begin{array}{l}4 \text { small groupings of } \\
\text { municipalities }\end{array}$ & $\begin{array}{l}2 \text { general directors of services } \\
2 \text { HRD } \\
\text { I administrative manager } \\
\text { I HR manager } \\
\text { I HR assistant }\end{array}$ & 10 to 49 \\
\hline $\begin{array}{l}\text { CDG (5 interviews at differ- } \\
\text { ent points in the progress } \\
\text { of the 'local GPEC' project }\end{array}$ & $\begin{array}{l}\text { I assistant director } \\
\text { I recruitment, employment, mobility } \\
\text { hub manager }\end{array}$ & 50 to 200 \\
\hline
\end{tabular}




\section{Typological lexical analysis}

The analysis of textual data is based on the analysis of the frequency of words in the text, considered as indicators of language acts (Austin, 1970) or as a trace of cognitive models (Johnson-Laird, 1994). Statistics on language decisions can be used to identify the factors likely to explain them. This exploratory analysis makes it possible to capture the major sets of concerns of the stakeholders without the bias of a reading through a model defined in advance. We used the Sphinx IQ2 Software, which allows us to perform a lexical and semantic analysis based on the frequency of the vocabulary used. Quotes characteristic of each category make it possible to interpret the themes thus revealed (Moscarola, 2018).

Content analysis. Thematic coding was done manually, double coding for 10 of the interviews. ${ }^{9}$ Our thematic grid was constructed from the literature review using a deductive approach. It included four main categories - contractualisation, individualisation, formalisation and politicisation logics - each divided into two subcategories (recruitment and other HRM practices).

\section{Logics concurrent to the hybridisation of practices}

\section{Results from the quantitative approach: characterisation of the HR logics of local authorities}

The Principal Component Analysis (PCR) performed on the 17 items with orthogonal varimax rotation $(\mathrm{KMO}=0.623)$ reveals four main factors (see Table 3$).{ }^{10}$

Factor 1 refers to the formalisation logic. The most saturated items relate to the existence of a job forecast, formal evaluation and recruitment procedures (with tools to objectify the choice, procedures, a job description process and CV evaluation grids). Factor 2 refers to the logic of individualisation. The most saturated items focus on the individualisation of remuneration and the implementation of knowledge and psycho-technical tests. Factor 3 relates to the logic of contractualisation, with the emphasis on employment contracts managed outside competition, the compensation scheme and the importance of the number of contract workers in the workforce. The variable 'simulations on the job or via a test at the time of recruitment' also contributes to the formation of factor 3 - 'contractualisation' - but to a lesser extent. In the survey conducted, this item was clearly linked to non-competitive recruitment practices. It thus illustrates the questioning of the single channel to access public sector jobs through competition, with local authorities opting here for practices of selecting candidates through tests and ad hoc situations. Finally, factor 4 relates to the logic of politicisation, with items relating to the role and influence of elected officials in recruitment practices (preferences given to candidates recommended by elected officials or who share their values; participation and influence of elected officials in recruitment decisions) and an item relating to the importance of non-permanent contract workers, also 


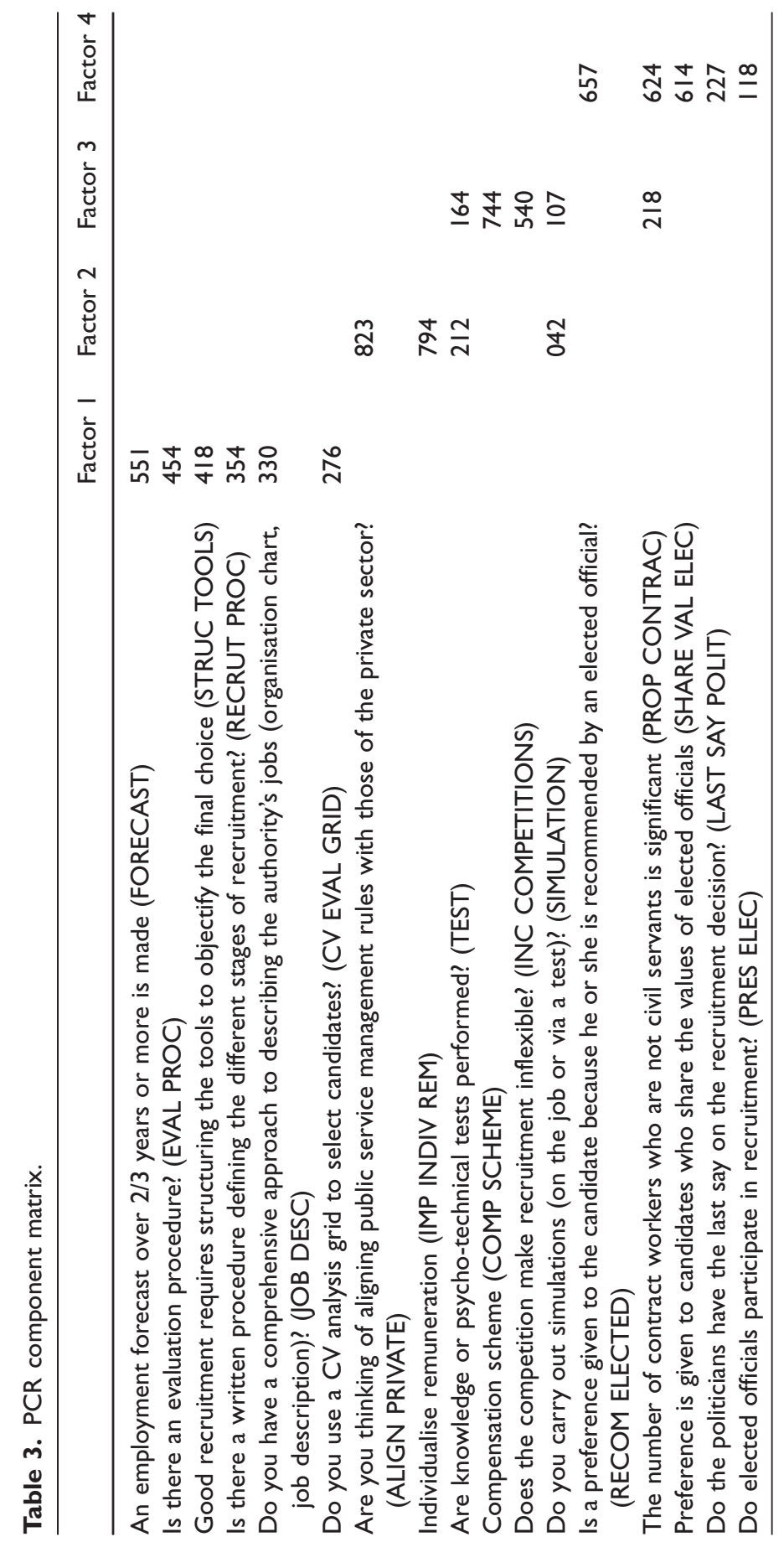


present in factor 3 (the link with politicisation may seem less obvious at first glance but can be interpreted as the desire of politicians to keep control over some of the recruitment, this being possible for non-civil servant contract workers). Figure 1 illustrates the results of the PCA through a diagram of the components in space after rotation. ${ }^{11}$

Degree of contractualisation of HRM. The results show that the logic of contractualisation is strong: in $40 \%$ of authorities, more than $80 \%$ of new recruits are noncivil servants (see Table 4). Moreover, 65.5\% of respondents believe that being a civil servant is not an important criterion in recruitment. Smaller authorities are the most likely to employ a very large majority of contract workers, while larger authorities are more likely to employ a small proportion of contract workers. More generally, and in all types of authorities, respondents are critical about competitive

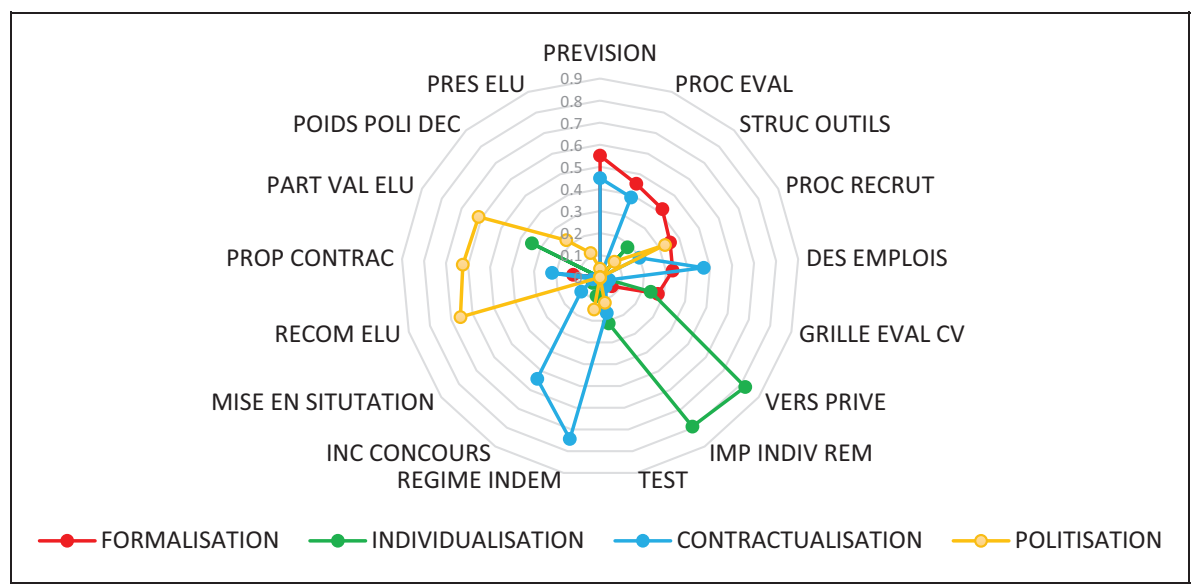

Figure I. Characterisation of the HRM logic of local authorities.

Table 4. Percentage of non-civil servant hires (among authorities that recruited in 2013) by authority size.

\begin{tabular}{llll}
\hline \multirow{2}{*}{$\begin{array}{l}\text { Percentage of recruitment } \\
\text { of non-civil servants }\end{array}$} & \multicolumn{2}{l}{ Size of the authority } & \\
\cline { 2 - 4 } & 0 to 5 & 6 to 20 & 2 21 and over \\
\hline Under $20 \%$ & $28.6 \%$ & $45.2 \%$ & $26.2 \%$ \\
$20 \%$ to $40 \%$ & $6.7 \%$ & $13.3 \%$ & $80 \%$ \\
$40 \%$ to $60 \%$ & $25.8 \%$ & $45.2 \%$ & $29 \%$ \\
$60 \%$ to $80 \%$ & $17.6 \%$ & $52.9 \%$ & $29.4 \%$ \\
$80 \%$ to $100 \%$ & $58.9 \%$ & $26 \%$ & $15.1 \%$ \\
\hline
\end{tabular}

Notes: $P=\inf 0.01$; ddl (Khi2: 43.38). 
recruitment: $60 \%$ of respondents believe that it does not provide the necessary skills and $78 \%$ see it as being inflexible.

Degree of individualisation of HRM. Respondents promote the individualisation of remuneration $(75 \%)$ and the approximation of private management rules $(60 \%)$.

Degree of formalisation of HRM. Overall, the formalisation of HRM processes is weak (see Tables 5 and 6). Most authorities have not defined the stages of recruitment, do not have a vacancy evaluation committee and do not use a CV analysis grid. Most of the traditional GPEC and HRM tools are absent in most authorities, with the exception of some tools needed for recruitment (job descriptions) and professional evaluation (which has replaced statutory rating).

Degree of politicisation of HRM. The degree of politicisation is reflected in the presence of politicians in HRM actions and the consideration of political criteria in management decisions. Elected officials play a predominant role in recruitment: in more than $90 \%$ of cases, the chief executive or another elected official is present in the recruitment committee (see Table 7). Moreover, the elected officials tend to have the most say in the final decision (see Table 8). In general, elected officials are very present in day-to-day management $(80 \%)$. In addition, some practices associated with cronyism still enjoy a certain legitimacy (see Table 9). The communal preference remains legitimate for most respondents. The other practices related to cronyism are mainly considered as illegitimate.

Table 5. Formalisation of recruitment processes.

Existence of the tool in the authority

Written recruitment procedure

$34.1 \%$

Job description process (job descriptions)

$65.4 \%$

Commission to evaluate the relevance of the republication of vacant positions

$17.2 \%$

Creation of job profiles for recruitment

$77.5 \%$

Existence of a CV analysis grid

$32.4 \%$

Table 6. Presence of GPEC (forward planning of employment and skills) tools.

Presence of the tool

Welcoming newcomers

$35 \%$

Internal mobility

$15.5 \%$

Professional evaluation

$63 \%$

Skill assessments

$17.9 \%$

Job and skills repositories

$12.6 \%$

Forward-looking approach to workforce management 
Table 7. Members of the organisation involved in recruitment.

\begin{tabular}{lll}
\hline Members present at the time of recruitment & $\begin{array}{l}\text { Non-executive } \\
\text { recruitment }\end{array}$ & $\begin{array}{l}\text { Executive } \\
\text { recruitment }\end{array}$ \\
\hline Chief executive officer & $50.4 \%$ & $57.1 \%$ \\
Other elected official & $45.1 \%$ & $42.9 \%$ \\
General director of services, general director & $36.9 \%$ & $37.6 \%$ \\
$\quad$ of administration, town hall secretary & & \\
HR staff & $21.7 \%$ & $23.5 \%$ \\
Head of the service in question & $25.5 \%$ & $15.9 \%$ \\
Future supervisor & $14.2 \%$ & $6.6 \%$ \\
\hline
\end{tabular}

Note: The overall percentage is greater than 100\% (multiple answers are possible).

Table 8. Stakeholders having the final say at the time of recruitment.

\begin{tabular}{llc}
\hline & $\begin{array}{l}\text { Non-executive } \\
\text { recruitment }\end{array}$ & $\begin{array}{l}\text { Executive } \\
\text { recruitment }\end{array}$ \\
\hline $\begin{array}{l}\text { Decision-making power held by: } \\
\text { Chief executive/elected officer }\end{array}$ & $63.7 \%$ & $82.8 \%$ \\
$\begin{array}{l}\text { General director of services, general director } \\
\text { of administration, town hall secretary }\end{array}$ & $18.2 \%$ & $12.6 \%$ \\
Head of the service in question & $15.8 \%$ & $4.6 \%$ \\
HR staff & $2.3 \%$ & $0 \%$ \\
\hline
\end{tabular}

Note: The overall percentage is greater than 100\% (multiple answers are possible).

Table 9. Legitimacy of practices associated with cronyism.

Is it acceptable to:

Prefer an applicant who lives in the municipality

Prefer an applicant who shares the values of the elected officials

Prefer an applicant who has social or financial difficulties

\section{Authority profiles in terms of HRM}

To assess the presence of a pro forma interplay of HRM logics, we used a nonhierarchical classification method (see Table 10 in Appendix 1). The five classes thus constituted are weakly correlated to the size of the authorities $(r=.14, p<.05)$ and not correlated to the nature of the authorities or the respondent (elected, DG, HR, etc.). The regressions show that size explains variation in the HRM logic to some extent (for politicisation and formalisation ${ }^{12}$ ) or not at all (for individualisation and contractualisation). 


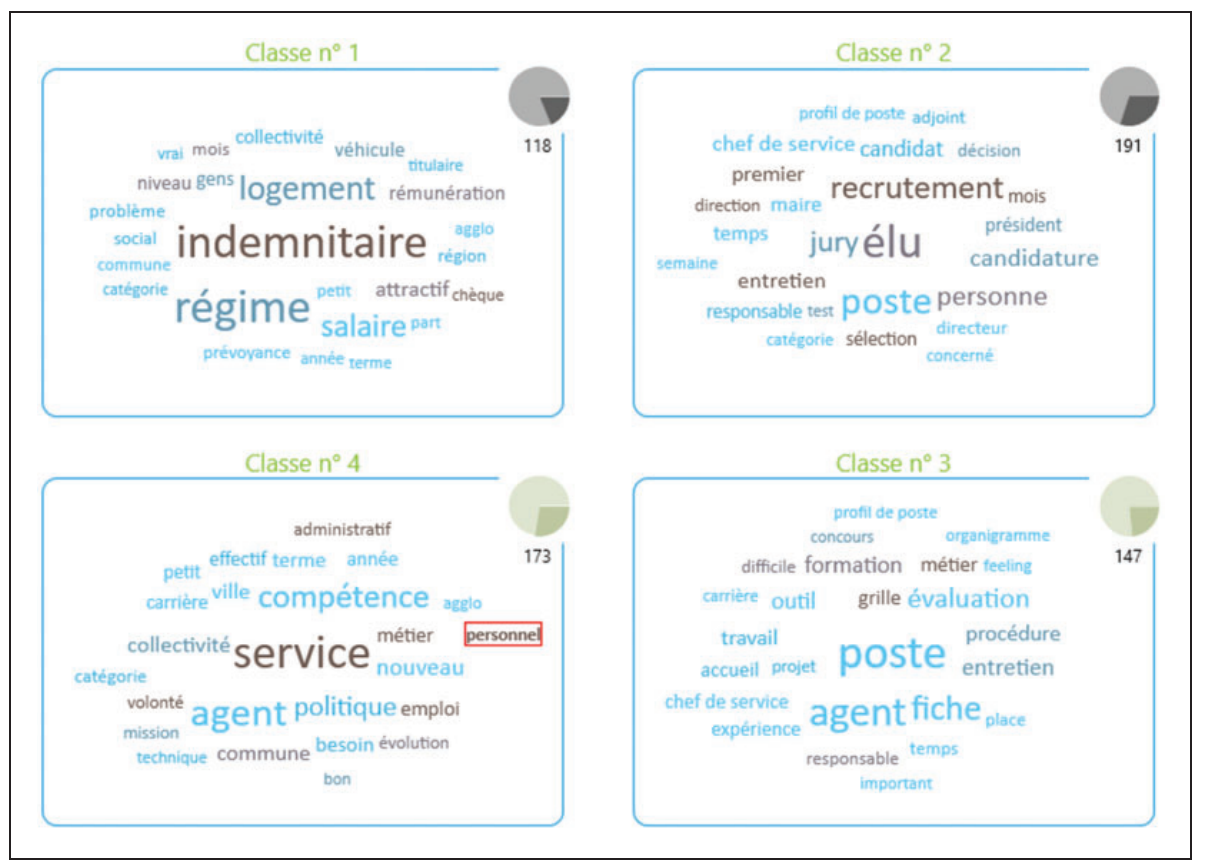

\section{Figure 2. $\square$.}

The results show that there is no pro forma interplay of logics. The majority of authorities have a weak combination of the four logics $(41.2 \%) ; 23 \%$ have a strong combination of the four logics. We then find three classes, each representing between $10 \%$ and $13 \%$ of the sample and corresponding to different combinations of logics: a class with politicisation + formalisation; a class with individualisation + formalisation; and a class with politicisation + contractualisation. The diversity of the combinations of logics thus reflects localised and multiple practices.

Thus, scenarios in which the privatisation of public HRM would result in the increased politicisation or formalisation of HRM are not confirmed, unlike the hybridisation scenario. It is therefore necessary to clarify how these logics are intertwined and negotiated in local practices, which is the subject of the qualitative part of our research.

\section{Results of the exploratory typological lexical analysis: confirmation of the presence of key HRM logics}

The lexical typological analysis of the quotes used to describe management practices made it possible to distinguish the following four classes (see Figure 2). With terms such as 'compensation scheme', 'remuneration' and 'permanent civil servant', class 1 refers to the contractualisation and individualisation of HRM. 
Indeed, these two elements refer to the questioning of the statutory logic in favour of a logic in which careers and remuneration are linked, above all, to the performance of individuals. Class 2 essentially refers to politicisation, through the presence of political stakeholders (elected official, mayor, president, deputy, etc.) in the recruitment process. Class 3 refers to the formalisation of HRM practices, with reference to $\mathrm{HR}$ processes. Class 4 refers more to administrative management processes (staff, category, career, etc.), which refers to the statutory approach. This analysis confirms the existence of the HRM logics previously identified by the ACP, even if the contractualisation and individualisation logics are associated by the respondents.

\section{Results of the content analysis: the example of negotiations between logics governing recruitment practices}

The analysis of the content of the interviews allows a more in-depth understanding of the mobilisation of logics and the hybridisation of HR practices.

\section{The four logics in practice}

Contractualisation. The civil servant status is envisaged as a system of constraints that would be alleviated by contractualisation. The difficulty in finding suitable candidates takes precedence over the question of compliance with legal rules. The most appropriate solution is often to recruit the 'best candidate' and then look for ways to regularise their situation with regard to the civil servant status: 'During pre-selection, the most important thing is competence. We are aware that we are killing off the statutory principle' (Human Resources Director, community of municipalities, 10 December 2013).

Individualisation. The main vector of individualisation is the compensation scheme: 'Our compensation system is interesting because it rewards, it recognises responsibility’ (HRD, municipality, 5 November 2013).

Formalisation. Most interviewees grant little importance to formalisation. The most common recruitment procedure is the creation of a job profile with or by the head of the department concerned, the advertising of the vacancy, then the screening of applications, and finally the establishment of a committee where elected officials are present. This committee decides on recruitment after hearing a short list of candidates, sometimes for a very short period (20-30 minutes). It is quite rare that these different stages are instrumented: 'For recruitment, we prefer the informal channels ... all the grids in the world will not replace the feeling' (general director of services, community of communes, 5 November 2013).

Politicisation. Elected officials have a significant influence on recruitment. Their opinion is often paramount: they are the ones who decide in the event of disagreement and who impose the essential criteria that will govern recruitment. 
Negotiations and adjustments between logics. The interviews show that the four logics compete in HR decisions and processes.

Arbitrations and power phenomena. The logics are driven by different stakeholders. Administrative workers promote formalisation and see supposedly rational management tools as a resource to influence recruitment processes: 'I'm certified to hold psycho-technical tests. The mayor opposed their use, although I had presented it to her as a support' (HRD, municipality, 4 December 2013). Conversely, elected officials promote politicisation by influencing recruitment processes and decisions, which is interpreted by some administrative officials as arbitrary practices: 'As politicians, there are people they want to place' (recruitment manager, municipality, 5 November 2013).

Given the growing illegitimacy of cronyism, this influence is reflected in the elected official's stated preference for a candidate, with the elected official generally having the last word, based on his or her personal feeling or opinions: "If the elected official tells us that it is candidate $\mathrm{A}$ when we wanted to recruit candidate B, it will be A!' (HRD, municipality, 4 December 2013). The theoretical contradictions between the different logics are not really identified by the stakeholders, who adopt an adaptive and pragmatic approach. The regulation between contradictory logics is only the subject of sporadic negotiations.

Decoupling over time. The contradictions between logics are also resolved by decoupling over time. Elected officials are generally present in the needs-definition stage. The administrative workers then take control of the publication, reception and first screening of applications, leaving the elected officials to make the final choice. This division of tasks allows the different logics to be deployed at different times during the recruitment process. Similarly, the statutory dimension, which is removed at the time of choice, is often reintegrated into subsequent stages. The logics can also be imposed in a cyclical way: attempts at formalisation (criteria grids, tests, etc.) launched by administrative workers are often gradually emptied of their meaning by elected officials who ignore them. Conversely, when there are recruitment failures, the statutory and formalisation logic regains ground.

\section{Discussion}

\section{A coexistence of logics}

Our analysis confirms the structuring dimensions of the logics of individualisation, contractualisation, formalisation and politicisation, and the hybridisation of these logics in HRM practices at the local government level. This hybridisation is not uniform. Contrary to the hypothesis of the convergence of HRM practices in developed countries (Nomdem, 2003), we do not observe a unidirectional trend: the hypotheses of evolution towards a scenario of individualisation or increased politicisation are not verified. 
Indeed, a great diversity of situations can be observed. Size offers some explanation for politicisation and formalisation but not for other logics. The combination of logics seems to be linked to specific aspects of the context of each local authority, such as the organisational culture, political history, personality and convictions of elected officials and leaders. Yet, the authorities studied are geographically and culturally close, are linked to a common resource centre (the CDG), and are part of a common economic context: economic dynamism, border effect, high cost of living and so on. The neo-institutional approach (Powell and DiMaggio, 2012) postulates that in an organisational field subject to the same environmental pressures, a mimicry takes place that leads organisations to adopt similar practices. On the contrary, our results show a significant diversity of combinations of logics. If mimicry does not take place, it is probably because environmental pressures are contradictory and multiple: it is necessary both to display effective practices and to ensure that the right of free administration of authorities is respected. A similar observation concerns the moves to dissolve the civil servant status (radical civil service reforms) undertaken in many American states. They do not lead to uniform results, whether between or within states (Condrey and Battaglio, 2007).

Thus, it is rather the micro-interactions specific to each authority that give a particular face to the compromise between these logics, according to Bishop and Waring's (2016) approach. HRM decisions are the scene of micro-negotiations in which logics compete (Battilana and Dorado, 2010) because they are mobilised in a differentiated way by the stakeholders.

\section{Importance of the political dimension}

The results of our research also highlight the importance of the political dimension in the HR practices of the authorities analysed. HR is an eminently political subject and elected officials are heavily involved in taking charge of these processes. This trend is not recent and was already observed in the 1960s and 1980s (Biland, 2012), when local employment was very much left to the local authority and characterised by political influence, social recruitment and certain forms of cronyism. The recent loosening of the civil servant status only intensifies competition between the logics.

This research thus shows the value of analysing 'ordinary politicisation' (Desmarais and Frank, 2017). Indeed, the intertwining of political and administrative logics is mainly analysed at the summit of public organisations (Desmarais and Giauque, 2016). Yet, these logics also play a role in the daily management practices of public organisations and give them a specific colour. However, this politicisation does not translate into the integration of political issues into HRM decisions, but rather translates into the existence of elected officials' decisions that give free rein to their 'feeling'. Thus, the politicisation of HRM is similar to the discretionary policy theorised by Pichault and Nizet (2013): a management often 
carried out without predefined criteria, with a predominance of the informal, making HR practices dependent on the will of 'enlightened' managers.

\section{Conclusion}

Public reforms linked to NPM have led to radical reforms of the civil service in many countries. At the time of our survey, local government in France had not undergone any major upheaval, but there was a marked tendency to develop HR practices that broke with the statutory framework. Yet, the loosening of the civil servant status is not spread so much by the formalisation of HR rules; rather, it partly favours the politicisation of HR processes and the development of contractualisation and individualisation. However, the main lesson of this research is that these different approaches are the subject of local negotiations, giving a very different face to the HR practices of local authorities, which nevertheless have to contend with similar challenges.

That being said, it should be noted that the authorities in our sample belong to the same geographical area and have common characteristics. A more restrictive context could perhaps be characterised by greater isomorphic pressures. To this essential limitation of the external validity of the analyses presented, a second one must be added, which concerns all the research that analyses organisational questions on the basis of the answers of a single stakeholder; indeed, its subjectivity necessarily colours the approaches mentioned. Finally, this research leads to new perspectives on the challenges of ordinary politicisation in managerial practices.

\section{Funding}

This research received no specific grant from any funding agency in the public, commercial or not-for-profit sectors.

\section{Notes}

1. 'Key figures 2017', French Department of Administration and the Civil Service (DGAFP).

2. A total of $19 \%$ in 2016, 'Key figures 2018', DGAFP. Available at: https://www.fonc tion-publique.gouv.fr/files/files/statistiques/chiffres_cles/pdf/CC-2018-web.PDF

3. A total of $56 \%$ of recruitments without competition to local government compared to $3.2 \%$ for the state civil service.

4. See: http://www.connexite.fr/a-la-une/fonction-publique-territoriale-individualisationau-coeur-politique-gestion-ressources-humaines 
5. See: https://www.collectivites-locales.gouv.fr/files/files/statistiques/brochures/chapitre_ 1_-_les_chiffres_cles_des_collectivites_locales_1.pdf

6. Executive leaders are increasingly making changes to the general management of local authorities in the wake of elections.

7. In 2014, the number of inhabitants stood at 783,127; in 2016, the unemployment rate was $7.2 \%$ (sixth French department in terms of its low unemployment rate).

8. Enrolment with a CDG is mandatory for local authorities employing fewer than 350 permanent civil servants or full-time trainees. The others may enrol on a voluntary basis.

9. With a reliability rate (number of identical codings/total number of codings performed $\times 100)$ of $86 \%$ for the 10 double-coded interviews.

10. The Barlett sphericity test $(\mathrm{X} 2(136)=259.331, p>.001)$ indicated that the correlations between the items did allow a PCR. Four components had eigenvalues greater than 1 and accounted for $62.68 \%$ of the variance in combination.

11. A word of thanks to one of the evaluators for suggesting that a graphical representation of PCA results be included to improve data presentation.

12. As the size of authorities increases, they are more formalised ( $2=0.40, F-$ ratio $=9.109, b$-value $=0.224, p<0.01)$ and less politicised $(\mathrm{R} 2=0.031, F$-ratio $=7.05$, $b$-value $=-0.206, p<0.01)$.

\section{References}

Austin JL (1970) Quand Dire, C'est Faire, How to Do Things with Words. Seuil.

Battilana J and Dorado S (2010) Building sustainable hybrid organizations: The case of commercial microfinance organizations. Academy of Management Journal 53(6): 1419-1440.

Biland E (2009) Moderniser les ressources humaines dans une petite ville française: Appropriations et contournements des normes juridiques et gestionnaires. Pyramides 17: $15-34$.

Biland E (2010) Les ambiguïtés de la sélection par concours dans la fonction publique territoriale: Une institutionnalisation inachevée. Sociologie Du Travail 52: 172-194.

Biland E (2012) La Fonction Publique Territoriale. Repère: La Découverte.

Bishop S and Waring J (2016) Becoming hybrid: The negotiated order on the front line of public-private partnerships. Human Relations 69(10): 1937-1958.

Bourdon J (1974) Le Personnel Communal. Paris: Berger Levrault.

Caciagli M and Jun'ichi K (2001) Heurs et malheurs du clientélisme. Revue Française de Science Politique 51(4): 569-586.

Cameron R (2010) La redéfinition des relations politico-administratives en Afrique du Sud. Revue Internationale des Sciences Administratives 76(4): 709-734.

Chevallier J (2002) Science Administrative. Paris: PUF.

Condrey SE and Battaglio RP (2007) A return to spoils? Revisiting radical civil service reform in the United States. Public Administration Review 67(3): 425-436.

Crozet P and Desmarais C (2004) Les habits neufs de la gestion des ressources humaines dans les villes depuis les lois de décentralisation: Vers une troisième voie? Revue Politiques et Management Public 22(2): 55-74.

De Kok J and Uhlaner LM (2001) Organization context and human resource management in the small firm. Tinbergen Institute Discussion Paper. Available at: http://www.tinbergen.nl

Demmke C and Moilanen T (2010) Civil Service in the EU of 27: Reform Outcomes and the Future of the Civil Service. Berlin: Peter Lang. 
Desmarais C (2008) The French research community's perspectives on New Public Human Resource Management. Public Management Review 10(1): 139-150.

Desmarais C and Frank C (2017) La politisation ordinaire: Analyse de l'impact du contexte public sur les activités managériales. 6ème congrès d'AIRMAP, Nice, 1-2 June.

Desmarais C and Giauque D (2016) Politique publique et management public, de nouvelles frontières? Gestion et Management Public 4(2): 1-7.

Dion S (1986) La Politisation des Mairies. Paris: Economica, Politique comparée.

Dreyfus F (2000) L'invention de la bureaucratie: Servir l'Etat en France, en Grande-Bretagne et aux Etats-Unis (XVIIIe-XXe) siècle. Paris: Découverte.

Emery Y and Giauque D (2014) L'univers hybride de l'administration au XXIème siècle. Revue Internationale de Sciences Administratives 80: 25-34.

Hood C (1996) Public management. In: The Oxford Handbook of Public Management. Oxford: Oxford University Press.

Hood C (2001) Public service bargains and public service reform. In: Peters BG and Pierre J (eds) Politicians, Bureaucrats and Administrative Reform. London: Routledge, ch. 2.

Johnson-Laird PN (1994) Mental models and probabilistic thinking. Cognition 50(1-3): 189-209.

Kim Y and Gao FY (2010) An empirical study of human resource management practices in family firms in China. The International Journal of Human Resource Management 21(12): 2095-2119.

Le Saout R (2011) La mobilité des directeurs généraux des services municipaux comme indicateur d'un rapport renouvelé au travail politique. Congrès AFSP, Strasbourg.

Moscarola J (2018) Faire Parler les Données. Paris: Edition EMS.

Norman R (2001) Letting and making managers manage: The effect of control systems on management action in New Zealand's central government. International Public Management Journal 4(1): 65-68.

Pichault F and Nizet J (2013) Pratiques de gestion des ressources humaines. Conventions, contextes et jeux d'acteurs.Paris, Editions du Seuil.

Peters BG and Pierre J (eds) (2004) Politicization of the Civil Service in Comparative Perspective. London: Routledge.

Pierre J (ed.) (1995) Bureaucracy in the Modern State: An Introduction to Comparative Public Administration. Aldershot: Edward Elgar.

Pierre J (2004) Politicisation of the Swedish civil service: A necessary evil or just evil. In: Peters BG and Pierre J (eds) Politicization of the Civil Service in Comparative Perspective. London: Routledge, pp. 41-54.

Pollitt C (1993) Managerialism and the Public Services: Cuts or Cultural Change in the 1990s? Cambridge: Blackwell Business.

Pollitt C and Bouckaert G (2004) Public Management Reform: A Comparative Analysis (2nd edn). Oxford: Oxford University Press.

Powell WW and DiMaggio PJ (eds) (2012) The New Institutionalism in Organizational Analysis. Chicago, IL: University of Chicago Press.

Rouban L (1998) Les transformations de l'action publique. Revue Française d'Administration Publique 86: 157-165.

Sadran P (1987) De l'allégeance à la mobilité: Quelle politisation pour la fonction publique territoriale? Pouvoirs (40): 39-48. 
Shim D-S (2001) Recent human resources development in OECD member countries. Public Personnel Management 30: 3.

Skelcher C and Smith SR (2015) Theorizing hybridity: Institutional logics, complex organizations, and actor identities: The case of nonprofits. Public Administration 93(2): 433-448.

Thiétart R-A (2014) Méthode de recherche en management (4th edn). Paris: Dunod, p. 656. 